\title{
EFFECT OF COMPETENCE, LEADER-MEMBER EXCHANGE AND TEAMWORK ON WORK DISCIPLINE, JOB STRESS AND THEIR IMPACT ON EMPLOYEE PERFORMANCE OF CONSTRUCTION COMPANY IN EAST JAVA, INDONESIA
}

\author{
Suprawa Tindra Adi*, Brahmasari Ida Aju, Brahmaratih Ida Ayu \\ University of Tujuh Belas Agustus 1945, Surabaya, Indonesia \\ *E-mail: tindraadisuprawa@yahoo.com
}

\begin{abstract}
Companies participating in an increasingly competitive world require strong employee support to build their long-term competitiveness. Therefore, performance should be a strategic value for the company. This study aims to evaluate the effect of competence, leader-member exchange and teamwork on work discipline, job stress and their impact on employee performance of Construction Company in East Java. The research method was quantitative approach with the sample of 230 respondents. Data were analyzed with Structural Equation Modeling using Amos 20.0 software. The results of this research show that competence has a significant influence on work discipline, but has no influence on job stress and performance. Leader-member exchange has a significant influence on work discipline, job stress, and employee performance. Teamwork has a significant influence on work discipline, but has no influence on job stress and employee performance. Work discipline and job stress have a significant influence on employee performance of Construction Company in East Java.
\end{abstract}

\section{KEY WORDS}

Competence, leader-member exchange, teamwork, job stress, employee, performance.

In an increasingly competitive era, companies must have an outstanding quality in order to win the competition. To achieve high performance, employees have an important role in running the organization. Performance is the work result that has a strong relationship with the strategic goals of the organization, consumer satisfaction, and economy contributor (Armstrong and Baron, 1998).

The organizational performance increases when the employees have the competence and discipline to carry out their responsibility. The organization is a social system with human resources (HR) as a determinant of effectiveness and efficiency (Rad and Yarmohammadian, 2006), which bring together many individuals, working teams, structures, systems, and rules agreed and implemented by all members of the organization (Von Bertalanffy, 1975 and Beer, 1980 in Senior and Swiles, 2004).

The numbers of personnel involved require resources management to contribute to the company's goals (Schermerhorn, 2008) by forming working teams with strong teamwork (Schein, 1988 in Senior and Swailes, 2004). Team performance is a key determinant of a company's success (Stashevsky and Koslowsky, 2006) and good working teams allow for new ideas and problem solutions (Chong, 2007).

The strength of the working team is internally determined by internal and external factors of employees. In the organizational context, every employee tries to change the organizational culture (Barkdoll, 2007) to better suit their personal values and competencies.

The strength of the working team cannot be separated from a leader. Wayne et al. (1997) state high team performance is a combination of individual performance, teamwork, and LMX. In addition to LMX, some researchers have shown that organizational support affects team performance (Miles and Mangold, 2002, Stashevsky and Koslowsky, 2006). Employees perceived organizational support will support back by giving the behavior the organization desires (Eisenberger et al., 1986). 
One theory related to employee support for the organization is the leader-member exchange (LMX), in which LMX is the related relationship between the leaders and the members. The basic theory of LMX is the relationship between leaders and employees in the collective bargaining processes to determine the role of each party and to keep in touch with each other (Dansereau et al., 1975) in Kanika et al. (2008). This relationship will affect various important factors for individuals and organizations (employee commitment, organizational commitment, satisfaction, employee performance, etc.) (Gerstner \& Day, 1998; Klein \& Kim, 1998) in Kanika et al. (2008).

Besides giving direct benefits to the organization, employees perceived organizational support are proved to increase organizational commitment (Rhoades et al., 2001; Settoon et al., 1996) in Kanika et al. (2008). The attitude of leaders in the leader-member exchange and the employee values and beliefs are directly related to the perceived satisfaction (Lange, 2008). On the other hand, the high commitment of group members provides energy, high discipline, and motivation to work better (Chan, 2006). Employees with high discipline, which means having the good morale to carry out their work, will ultimately have higher performance (Wardana, 2008).

Based on the above phenomenon, the researchers conduct more in-depth research on the effect of competence, leader-member exchange, and teamwork on work discipline and job stress and their impact on employee performance.

Research Objectives. Based on the background and research problems, this study aims to examine and analyze: effect of competence on employee work discipline of Construction Company in East Java; effect of competence on employee job stress of Construction Company in East Java; effect of competence on employee performance of Construction Companies in East Java; effect of LMX on employee work discipline of Construction Company in East Java; effect of LMX on employee job stress of Construction Company in East Java; effect of LMX on employee performance of Construction Company in East Java; effect of teamwork on employee work discipline of Construction Companies in East Java; effect of teamwork on employee job stress of Construction Company in East Java; effect of teamwork on employee performance of Construction Companies in East Java; effect of work discipline on employee performance of Construction Companies in East Java; effect of job stress on employee performance of Construction Company in East Java.

\section{LITERATURE REVIEW}

Competence. Conceptually, competence is the basic characteristic of an individual that influences the way of thinking and acting, generalizes to all encountered situations, and exists for a quite long time (Spencer \& Spencer, in Ruky, 2015).

Competence is formed based on motives, personal traits, self-concept, knowledge, and skills. The definition proposed by Spencer \& Spencer (Ruky, 2015) describes that "Comparative Criteria" should be applied in using the concept of competence to show the effect of competence on work performance.

Based on the above description, it can be concluded that competence is the ability and willingness to perform a task with effective performance. Armstrong (2004) states competence is knowledge, skill, and quality of the individual. In addition, Watson Wyatt (Ruky, 2015: 106) defines competence as a combination of skills, knowledge, and behaviors that can be observed and applied critically for the success of the organization and work performance as well as employee personal contribution to the organization.

'To contribute to the company, Spencer \& Spencer (in Ruky, 2015: 106) also explain that competence, in relation to performance, can be classified into two types: Threshold Competencies, i.e. minimal and essential criteria; and Differentiating Competencies, i.e. criteria that can distinguish between people with superior performance and people with average performance.

Leader-Member Exchange (LMX). Morrow et al., (2005) states that Leader-member exchange (LMX) as the relationship between a supervisor and an employee to improve the work performance. Good treatment to employees is able to create voluntary feelings to 
sacrifice for the company. In addition, positive special treatment is able to increase the contribution of employees to their companies.

Truckenbrodt (2000: 233) states that the leader-member exchange focuses on the assessment of the work-related relationship and interaction between supervisors and subordinates. Proximity level of the relationship between the leaders and subordinates is an indicator of the leader-member exchange in the organization.

In an organization, there may be a different relationship between the leader and the subordinates. Proximity level of the relationship is usually called as the leader-member exchange. According to Welliam (2003: 1), the theory of leader-member exchange put the concept of relationship as the basis of assessment. In an organizational environment, the leader-member exchange leads to the relationship between the leader and the employees as the subordinates.

According to Leonard (2002) in Bagus (2009), the understanding of the leader-member exchange is not only on the physical bond, in which the subordinate should continuously follow the instructions of the leader, but also on the deeper bond of interaction between employees and leader. This interaction bond involves an emotional bond between employees and leader.

According to Graen and Cashman (1975), employee group in Leader-member exchange can be identified from the special treatment given to the employee; adequate attention from the employee's leader; trust the leader gives to the employees and vice versa; willingness to accept additional responsibility from the company; employee willingness to accept unstructured tasks; and employee willingness to perform additional work voluntarily in the company.

Teamwork. Teamwork is the ability of team members to work together, communicate effectively, anticipate and meet each other needs, and stimulate confidence to generate coordinated collective action (Gregory, 2012).

Teamwork refers to interpersonal activities that facilitate the goals achievement (Colquitt, et al., 2011). There are three components in teamwork: i.e. togetherness, trust, and integrity (Kreitner and Kinicki, 2007).

Teamwork is a special form of the working group that must be organized and managed differently from other working groups (Dewi, 2007). The team consists of people coordinated to work together with strong interdependence to achieve a goal or accomplish a task. In general, Griffin (2004) divides the development of a team into four stages: Forming, Storming, Norming and Performing.

Thus, teamwork is a group in which the individual produces a performance level greater than the number of individual inputs (Robbins and Judge, 2008). West (2002) details 4 (four) strengths in building an effective team, namely:

1. Groups should have intrinsically interesting tasks to succeed;

2. Individuals should feel important to the group's outcome;

3. Individual contributions should be indispensable, unique, and tested;

4. There should be clear team goals with regular performance feedback.

Work Discipline. Discipline is the awareness and willingness of a person to comply with all principal organizational rules and social norms. Awareness is the attitude of a person who voluntarily obeys all rules and is aware of his/her duties and responsibilities. Willingness is an attitude, behavior, and actions of a person in accordance with the rules of the company whether written or not (Hasibuan, 2001).

Heidjrachman and Husnan (2002) state that discipline includes every individual and group ensuring compliance with orders and taking the initiative to take the necessary action in the absence of an order.

Hasibuan (2001) explains that there are indicators that affect the level of discipline of employees, i.e. (1) goals and abilities, (2) leaders examples, (3) remuneration (salary and welfare), (4) justice, (5) inherent supervision, (6) penalty sanctions, (7) assertiveness, and (8) human relations.

Work discipline is one of the operative functions of human resource management that reflects a person's sense of responsibility towards the tasks assigned. According to Mathis 
(2000), this variable of work discipline can be measured using the following indicators: Attendance, Timeliness of work, and Regulatory compliance.

Job Stress. Job stress is a condition arises from the interaction between human and work. It is characterized by human changes that force them to deviate from their normal function. Job stress is a serious problem afflicting every employee in the workplace. Stress is a state of tension affecting the emotions, thinking processes, and conditions of a person (Handoko, 2008). Excessive stress threatens someone capability to complete the job and to achieve work performance.

Job stress can be seen from the emergence of complaints from employees about work problems. Employee complaint includes the number of workloads that must be completed because some employees are not able to utilize the existing working time, causing the work cannot be completed on time.

Luthans (in Yuwono et al., 2006) suggests that many managers report work-related stress, and the new environment worsens the atmosphere.

Employee Performance. Performance is not only about productivity because performance concerns the natural behavior of a person to freely act upon his/her wishes. This free-to-act behavior cannot be separated from the formal requirements of an employee's role to improve the effective functioning of an organization (Rich, 1997). Employee productivity (performance) is the comparison between the achieved outcomes and employee participation per unit of time, while employee participation is the efficient and effective use of resources.

Meanwhile, according to Sager (1984), employee productivity is influenced by education, skills, discipline, work attitude and ethics, motivation, health, income, work climate, etc.

From the description above, it can be concluded that good employee or individual performance causes better organizational performance and stronger trust for the organizations (Erran, 2003). Podsakoff et al. (1998) divide employee performance into: in role performance is the performance related to the job in regard to effectiveness, sales volume, managerial evaluation, and matters relating to the target to be achieved; extra role performance is the performance related to spontaneous and contextual pro-social behavior.

Concept Framework of the Research. Conceptually, this research aims to know the effect of competence (X1), LMX (X2) and Teamwork (X3). This research used discipline (Z1) and job stress (Z2) as the intervening variable, with Employee Performance $(Y)$ as the dependent variable. Graphically, the conceptual framework of this research is as seen from Figure 1.

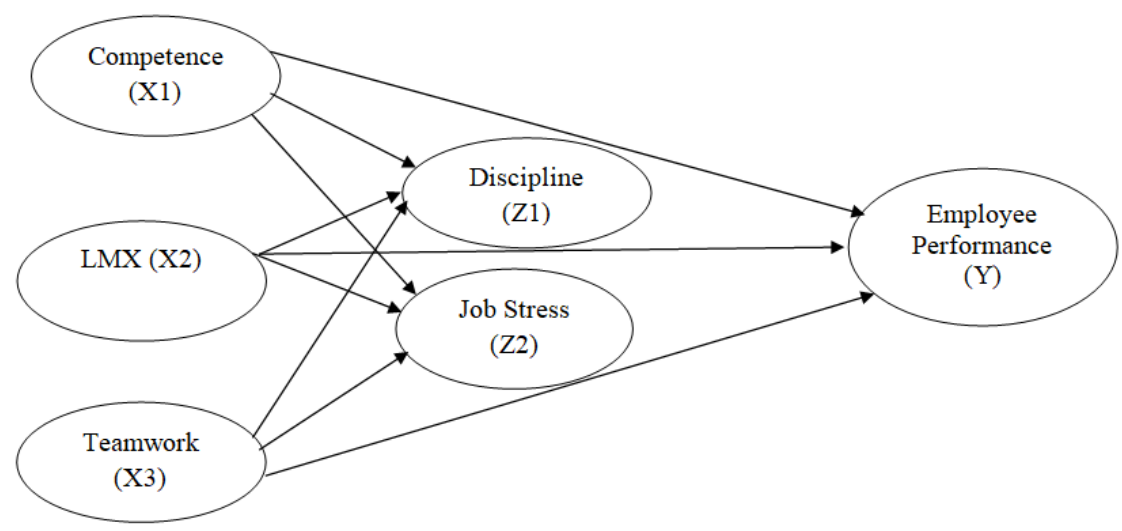

Figure 1 - Conceptual Framework

\section{METHODS OF RESEARCH}

Population and Sample of the Research. According to Sugiyono (2012), the population is a generalization area consisting of objects/subjects that have certain qualities and 
characteristics set by the researchers to be studied and then drawn conclusions. Meanwhile, Nazir (2004) argues that population is concerned with the data, not the person or the object. The population of this research was 1,487 employees in 5 construction companies in East Java. Furthermore, the sample size of respondents for each company was determined proportionally, i.e. 230 respondents.

Table 1 - Operational Definition of Variables

\begin{tabular}{|c|c|c|c|}
\hline Variable & Definition & Indicator & Literature \\
\hline Competence & $\begin{array}{c}\text { the basic characteristic of an individual that } \\
\text { influences the way of thinking and acting, } \\
\text { generalizes to all encountered situations, } \\
\text { and exists for a quite long time }\end{array}$ & $\begin{array}{c}\text { Knowledge, skill, and } \\
\text { self-concept }\end{array}$ & $\begin{array}{l}\text { Spencer \& Spencer, } \\
\text { (2003), Ruky (2006). }\end{array}$ \\
\hline $\begin{array}{l}\text { Leader- } \\
\text { member } \\
\text { exchange } \\
\quad(\text { LMX) }\end{array}$ & $\begin{array}{l}\text { Leader-member exchange focuses on the } \\
\text { assessment of the work-related } \\
\text { relationship and interaction between } \\
\text { supervisors and subordinates. Level of the } \\
\text { proximity to this relationship between the } \\
\text { leaders and subordinates is an indicator of } \\
\text { the leader-member exchange in the } \\
\text { organization. }\end{array}$ & $\begin{array}{l}\text { Adequate attention from } \\
\text { the employee's leader, } \\
\text { Trust the leader gives to } \\
\text { the employees, and } \\
\text { Willingness of } \\
\text { employees to perform } \\
\text { additional work }\end{array}$ & $\begin{array}{l}\text { Morrow, et al., (2005); } \\
\text { Bagus (2009), } \\
\text { Truckenbrodt, } 2000\end{array}$ \\
\hline Teamwork & $\begin{array}{l}\text { Teamwork is the ability of team members } \\
\text { to work together, communicate effectively, } \\
\text { anticipate and meet each other needs, and } \\
\text { stimulate confidence to generate } \\
\text { coordinated collective action }\end{array}$ & $\begin{array}{c}\text { Participatory leadership } \\
\text { Shared responsibilities } \\
\text { Unified objectives } \\
\text { Intensive } \\
\text { communication } \\
\text { Focus on the job } \\
\text { Out-of-work demands } \\
\end{array}$ & $\begin{array}{l}\text { Leonard (2013); } \\
\text { Gregory (2012); } \\
\text { Kreitner and Kinicki } \\
\text { (2007). }\end{array}$ \\
\hline $\begin{array}{c}\text { Work } \\
\text { Discipline }\end{array}$ & $\begin{array}{l}\text { Work discipline is one of the operative } \\
\text { functions of human resource management } \\
\text { that reflects a person's sense of } \\
\text { responsibility towards the tasks assigned. }\end{array}$ & $\begin{array}{c}\text { Attendance } \\
\text { Timeliness of work } \\
\text { Regulatory compliance }\end{array}$ & $\begin{array}{l}\text { Mathis (2000), } \\
\text { Hasibuan (2013), } \\
\text { Mangkunegara } \\
\text { (2005). }\end{array}$ \\
\hline Job Stress & $\begin{array}{l}\text { Job stress is a condition arises from the } \\
\text { interaction between human and work. It is } \\
\text { characterized by human changes that force } \\
\text { them to deviate from their normal function. }\end{array}$ & $\begin{array}{c}\text { Duty demands } \\
\text { Role conflict } \\
\text { Role ambiguity } \\
\text { Career development } \\
\text { Working relationship }\end{array}$ & $\begin{array}{l}\text { Handoko (2009), Fred } \\
\text { Luthans (2006), } \\
\text { Hurrel et.al., 1988 } \\
\text { (Ashar Sunyoto } \\
\text { Munandar, 2008) }\end{array}$ \\
\hline $\begin{array}{c}\text { Employee } \\
\text { Performance }\end{array}$ & $\begin{array}{l}\text { Employee performance is a result of the } \\
\text { quality and quantity of work that can be } \\
\text { achieved by an employee in performing } \\
\text { tasks in accordance with the } \\
\text { responsibilities. }\end{array}$ & $\begin{array}{l}\text { Quality of work } \\
\text { Quantity of work } \\
\text { The timeliness of work }\end{array}$ & $\begin{array}{l}\text { Ruky (2015), Nawawi } \\
\text { (2007). Timpe (2003) }\end{array}$ \\
\hline
\end{tabular}

Measurement Scale. To measure the required data, the Likert Scale was used in this study. The Likert scale is used through 5 levels with the following scores:

a. Strongly agree / highly capable category with score 5

b. Agree / capable category with score 4

c. Less agree / quite capable category with score 3

d. Disagree / incapable category with score 2

e. Strongly disagree / highly incapable category with score 1

Data Collection Technique. This study used primary data by conducting direct observation, questionnaire, and interview with the most efficient design in accordance with the tools, techniques, and characteristics of the respondents (Nazir, 2004: 108). The techniques used to collect primary data were preliminary surveys, interviews, and questionnaires.

Data Analysis Technique. Data analysis in this research used Structural Equation Modeling (SEM) analysis because this analysis method can give simultaneous analysis process related to multi-variant research model. Before the data were analyzed with SEM, the validity and reliability tests were conducted first. 


\section{RESULTS OF STUDY}

Based on the results of data analysis with SEM model, the Standardized Regression Weight results are seen from Table 2.

Table 2 - Hypothesis testing using Regression Weight Test

\begin{tabular}{|c|c|c|c|c|c|c|c|c|}
\hline \multicolumn{3}{|c|}{ Causality relationship } & \multicolumn{2}{|l|}{$\begin{array}{l}\text { Direct } \\
\text { Effect }\end{array}$} & \multirow{2}{*}{$\begin{array}{c}\text { Indirect Effect } \\
\left.\text { (Through } \mathrm{Z}_{1}\right) \\
-\end{array}$} & \multirow{2}{*}{$\begin{array}{c}\text { Indirect Effect } \\
\text { (Through } \mathrm{Z}_{2} \text { ) } \\
-\end{array}$} & \multirow{2}{*}{$\begin{array}{c}\begin{array}{c}\text { Total } \\
\text { Effect }\end{array} \\
0.111\end{array}$} & \multirow{2}{*}{$\begin{array}{l}\text { Note } \\
\text { Note }\end{array}$} \\
\hline $\begin{array}{c}\text { Competence } \\
\left(\mathrm{X}_{1}\right) \\
\end{array}$ & $\rightarrow$ & $\begin{array}{c}\text { Work discipline } \\
\left(Z_{1}\right)\end{array}$ & 0.111 & 0.076 & & & & \\
\hline $\begin{array}{c}\text { Competence } \\
\left(\mathrm{X}_{1}\right)\end{array}$ & $\rightarrow$ & Job Stress $\left.\left(Z_{2}\right)\right)$ & -0.270 & 0.000 & - & - & -0.270 & $\begin{array}{c}\text { Not } \\
\text { Significant }\end{array}$ \\
\hline $\begin{array}{c}\text { Competence } \\
\left(\mathrm{X}_{1}\right) \\
\end{array}$ & $\rightarrow$ & $\begin{array}{c}\text { Employee } \\
\text { performance }(Y)\end{array}$ & 0.274 & 0.000 & 0.043 & 0.040 & 0.357 & Significant \\
\hline $\operatorname{LMX}\left(\mathrm{X}_{2}\right)$ & $\rightarrow$ & $\begin{array}{c}\text { Work discipline } \\
\left(Z_{1}\right)\end{array}$ & 0.343 & 0.000 & - & - & 0.343 & Significant \\
\hline $\operatorname{LMX}\left(\mathrm{X}_{2}\right)$ & $\rightarrow$ & Job Stress $\left(Z_{2}\right)$ & -0.437 & 0.000 & - & - & -0.437 & Significant \\
\hline $\operatorname{LMX}\left(X_{2}\right)$ & $\rightarrow$ & $\begin{array}{c}\text { Employee } \\
\text { performance }(Y)\end{array}$ & 0.111 & 0.097 & 0.133 & 0.065 & 0.309 & Significant \\
\hline Teamwork $\left(\mathrm{X}_{3}\right)$ & $\rightarrow$ & $\begin{array}{c}\text { Work discipline } \\
\left(Z_{1}\right)\end{array}$ & 0.293 & 0.000 & - & - & 0.293 & $\begin{array}{c}\text { Not } \\
\text { Significant }\end{array}$ \\
\hline Teamwork $\left(\mathrm{X}_{3}\right)$ & $\rightarrow$ & Job Stress $\left(Z_{2}\right)$ & -0.372 & 0.000 & - & - & -0.372 & Significant \\
\hline Teamwork $\left(\mathrm{X}_{3}\right)$ & $\rightarrow$ & $\begin{array}{c}\text { Employee } \\
\text { performance }(\mathrm{Y})\end{array}$ & 0.166 & 0.008 & 0.114 & 0.055 & 0.335 & Significant \\
\hline $\begin{array}{c}\text { Work discipline } \\
\left(Z_{1}\right)\end{array}$ & $\rightarrow$ & $\begin{array}{c}\text { Employee } \\
\text { performance }(\mathrm{Y})\end{array}$ & 0.389 & 0.000 & - & - & 0.389 & Significant \\
\hline Job Stress $\left(Z_{2}\right)$ & $\rightarrow$ & $\begin{array}{c}\text { Employee } \\
\text { performance }(\mathrm{Y})\end{array}$ & -0.148 & 0.041 & - & - & -0.148 & Significant \\
\hline
\end{tabular}

\section{DISCUSSION OF RESULTS}

Effect of Competence on Work Discipline. The results of hypothesis testing using SEM method prove that competence has no significant effect on the employee work discipline of Construction Company in East Java. The results of this study contrast with Sofo's (1999) findings in Andersen that competence refers to a person's ability to respond and behave adequately to changes and how they achieve good performance and results. Therefore, the better the competence is, the higher the work discipline will be. No significant influence of the competence on the work discipline is due to unfavorable habits. Competent employees tend to feel more confident about timely and good work result, causing less attention to the work discipline. Employees consider that as long as they have competence, their performance is still better even though their work discipline is low.

Effect of Competence on Job Stress. The results of hypothesis testing show that competence has a significant effect on employee job stress of Construction Company in East Java. This result indicates that highly competent employees tend to have low job stress.

The results of this study are consistent with Sofo's (1999) findings in Andersen that employees utilize competence to finish their work in accordance with the present rules or norms. Consequently, the job stress is low.

Effect of Competence on Employee Performance. The findings of this study show that competence has a significant effect on employee performance. These findings are in line with Sofo's (1999) findings in Andersen that competence the employees have causes them to be able to do their job properly, causing higher work satisfaction as well. In the end, it will trigger high performance.

Effect of LMX on Work Discipline. The influence of Leader-Member Exchange Contributions (LMX) on work discipline is 0.343 (positive). It indicates that the better LeaderMember Exchange Contributions (LMX) is, the higher the employee work discipline will be.

The results of this study confirm Bhal et al.'s (2009) findings that LMX affects various important factors for individuals and organizations (e.g. employee objective commitment, organizational commitment, discipline, employee performance, etc.). Employees perceived organizational support will actively pursue organizational goals. 
Effect of LMX on Job Stress. The influence of Leader-Member Exchange Contributions (LMX) on job stress is -0.437 (negative). It indicates that the better Leader-Member Exchange Contributions (LMX) is, the lower the employee job stress will be.

These findings support Eisenberger et al.'s (1986) findings that employees perceived organizational support will support back by giving the behavior the organization desires. Besides giving direct benefits to the organization, employees perceived organizational support are proved to feel satisfied and to have less stress.

Effect of LMX on Employee Performance. The results of this study indicate that a good Leader-Member Exchange Contributions (LMX) is less capable to improve employee performance. The results of this study are in contrast to Eisenberger et al.'s (1986) findings that employees perceived organizational support will strive to increase their commitment to the organization by implementing all the obligated rules in the organizations.

The non-significant effect of LMX directly on employee performance is due to the low work discipline. A good relationship between the leaders and the employees without high work discipline will not have an optimal impact on improving employee performance.

Effect of Teamwork on Work Discipline. The results show that teamwork has a significant effect on employee work discipline of Construction Company in East Java. The high level of teamwork influence on work discipline shows that the better the teamwork is, the better the employee discipline will be. The results of this study confirm Kreitner and Kinicki's (2005) findings that there is a relationship between group unity and work discipline.

Effect of Teamwork on Job Stress. The teamwork influence on job stress is negative. It indicates that the better the teamwork is, the lower the employee stress will be.

The results of this study corroborate Robbins and Judge's (2008) findings that teamwork generates positive synergies through coordinated efforts, individual efforts generate high satisfaction, and high job satisfaction affects low job stress. Training and development are also very important in improving teamwork and are part of the human resource management phase.

Effect of Teamwork on Employee Performance. Teamwork influence on employee performance is positive. It shows that the better the teamwork is, the better the employee performance will be. The results of this study are in line with Robbins and Judge's (2008) findings that teamwork generates positive synergies through coordinated efforts and individual efforts produce a higher level of performance than the number of individual inputs. A higher level of performance means that employees working with coordinated teamwork will create work achievement through the quality and quantity of their work.

Effect of Work Discipline on Employee Performance. The results of this study indicate a significant influence of work discipline on employee performance. It shows that the better the work discipline is, the better the employee performance will be.

The results of this study are consistent with Hasibuan's (2000) findings that discipline is categorized as good when employees come to the office or company regularly and on time, dress well in the workplace, use materials and equipment carefully, produce satisfying quantity and quality of work, follow the rules determined by the company, and finish the work very well. Discipline is so important that it affects the results of employee work performance. Therefore, work discipline should be encouraged in every organization (1994).

Effect of Job Stress on Employee Performance. The effect of job stress on employee performance is negative. It shows that the higher the employee job stress is, the lower the employee performance will be.

The findings are in line with Mangkunegara's (2008) findings that the causes of job stress include overloaded work, pressing work time, low quality of work supervision, unhealthy work climate, inadequate work authority associated with responsibility, work conflicts, and value differences between employees and frustrated leaders in work.

The findings support Indriyani's (2009) study that job stress variable negatively affects employee performance. Job stress variables have a negative and significant effect on employee performance variable. The higher the job stress is, the lower the employee performance will be (Rozikin, 2006). 


\section{CONCLUSION}

Based on the results of the analysis, hypothesis testing, and the research objectives, it can be concluded that:

- Competence has no significant effect on employee work discipline of Construction Company in East Java. High employee competence will not have a major impact on work discipline.

- Competence has a significant effect on employee job stress of Construction Company in East Java. High employee competence will reduce the level of job stress.

- Competence has a significant effect on employee performance of Construction Company in East Java. High employee competence will improve their performance.

- Leader-Member Exchange Contributions (LMX) has a significant effect on employee work discipline of Construction Company in East Java. High Leader-Member Exchange Contributions (LMX) will improve employee work discipline.

- Leader-Member Exchange Contributions (LMX) has a significant effect on employee job stress of Construction Company in East Java. High Leader-Member Exchange Contributions (LMX) will reduce employee job stress.

- Leader-Member Exchange Contributions (LMX) has no significant effect on employee performance of Construction Company in East Java. High Leader-Member Exchange Contributions (LMX) will not have a major impact on improving employee performance.

- Teamwork has a significant effect on employee work discipline of Construction Company in East Java. Strong teamwork will improve employee work discipline.

- Teamwork has a significant effect on employee job stress of Construction Company in East Java. Strong teamwork will reduce employee job stress.

- Teamwork has a significant effect on employee performance of Construction Company in East Java. Strong teamwork will improve employee performance.

- Work discipline has a significant effect on employee performance of Construction Company in East Java. High work discipline will improve employee performance.

- Job stress has a significant effect on employee performance of Construction Company in East Java. Low job stress will improve employee performance.

\section{IMPLICATION AND LIMITATIONS}

This research has implications for the development of economics, especially the importance of competence, Leader-Member Exchange Contributions (LMX), and teamwork in improving work discipline and reducing job stress. In addition, high work discipline and low job stress are able to improve employee performance as well.

Based on the results of the previous analysis, the limitation of this study is that this research was conducted on the employees of Construction Company in East Java with limited survey time. This study did not distinguish employees based on the length of work which may influence the assessment. Employees with a high working period may have different experience and competencies from employees with a low working period.

\section{REFERENCES}

1. Amiruddin, P. (2011). Pengaruh Leader Member Exchange terhadap Komitmen Organisasi pada PT Midian Karya Pasuruan. Jurnal Manajemen Bisnis, 201-2015

2. Anisa, N. (2008). Hubungan Motivasi Kerja dan Disiplin Kerja dengan Produktivitas Kerja Pegawai Dinas Pekerjaan Umum Kabupaten Grobogan (Disertasi). Universitas Diponegoro, Semarang

3. Bagus, D. (2009). Leader Member Exchange (LMX) dalam Konteks Kepemimpinan,. Journal SDM 27 (3), 11-22 
4. Bateman, T.S., \& Organ, D.W. (1993). Job Satisfaction and the Good Soldier: The Relationship between affect and Employee Citizenship. Academy of Management Journal, 26 (7) 587-594.

5. Buchholz, A., \& Wordmann, A. (2000). What Makes Hidden Method Behind the World's Most Successful Brands. Chicester: John Wiley and Sons.

6. Chien, M. H. (2004). A Study to Improve organizational performance: A View from SHRM. The Journal of American Academy of Business 25 ( 3) 219-232

7. Colquitt, J.A., Scott, B.A., \& LePine, J.A. (2011). Trust, trustworthiness, and trust propensity: A meta-analytic test of their unique relationships with risk taking and job performance. Journal of applied psychology, 92(4), 909-927.

8. Devis, K., \& Jhon, W. N. (2004). Perilaku Dalam Organisasi, Alih bahasa Agus Dharma. Jakarta: Erlangga.

9. Djati, S. P. (2009) Variabel Anteseden Organizational Citizenship Behavior (OCB) dan Pengaruhnya Terhadap Service Quality pada Perguruan Tinggi Swasta di Surabaya, Jurnal Aplikasi Manajemen (JAM), 7(3), 26-33

10. Erin, A. W., \& Eddy, M. S. (2013). Pengaruh Leader Member Exchange Terhadap Kepuasan Kerja, Motivasi Kerja dan Komitmen Organisasional Karywan Departemen Penjualan pada PT. X. AGORA, 1 (1), 312-328

11. Flippo, E. B. (2004). Personel Management (Sixth Ed). Translated Moh. Mas'ud. Jakarta: Erlangga.

12. Garry, A. G., Paul, D., \& Patrick, G. (2006). National Differences In organizational Commitment: Effect of Economy, Product of Personality, or Consequence of Culture. Journal of Cross-Culture Psychology 14 (7) 542-556.

13. Griffin W., Ricky., Gregory., \& Moehead, (2004). Organizational Behavior. New York: Houghton Miffin Company.

14. Harrmon, J., Scotti, D. J., Behson, S., Faries, G., Petzel, R., Neuman, J. H., \& Keashly, L. (2003). Effect of High Involvemnet Work System on Employee Satisfaction and Service Cost in Veterans Healtthcare. Journal of Healtthcare Management, 48 (6), 517- 536

15. Hasibuan, M. S. P. (2013). Manajemen Sumber Daya Manusia, Jakarta: PT. Bumi Aksara.

16. Hersey, P. K. H., Blanchard., \& Dewey, E. J. (2001). Management of Organizational Behavior: Utilizing Human Resources. New Jersey: Prentice Hall, Inc.

17. Ida, A. B., \& Peniel, S. (2009). Pengaruh Budaya Organisasi, Kepemimpinan Situasional Dan Pola Komunikasi Terhadap Disiplin Kerja dan Kinerja Karyawan Pada PT Central Proteinaprima Tbk. Jurnal Aplikasi Manajemen, 7(1), 132-147

18. Indrawijaya, A. I. (2002). Perilaku Organisasi. Bandung: Sinar Baru Algensindo.

19. Iverson, R. D. (1996). Employee Acceptance of Organizational Change: The Role of Organizational Commitment. The International Journal of Human Resource Management, $7(1), 122-149$.

20. Jeongkoo, Y., \& Shaner, R. T. (2002). A Dual Process Model Of Organizational Commitment: Job Satisfaction and Organizational Support. Retrieved from http://wox. sagepublications.com.

21. Kinicki, A., \& Kreitner, R. (2007). Organizational Behavior. New York: The Mc. Graw-Hill Companies, Inc.

22. Koesmono, H. T. (2005). Pengaruh Budaya Organisasi terhadap Motivasi dan Kepuasan Kerja serta Kinerja Karyawan pada Sub Sektor Industri Pengolahan Kayu Ekspor di Jawa Timur (Disertasi). Universitas Airlangga, Surabaya.

23. Kusdiantina, E., \& Thoyib, A. (2006). Analisis Pengaruh Pengembangan Karier, Kepuasan Kerja dan Kinerja Karyawan suatu Studi pada Karyawan Universitas Brawijaya Malang. Jurnal Aplikasi Manajemen (JAM), 26 (2) 534- 544.

24. Lau, C., \& WoodMan, R. C. (1995). Understanding Organizational Change: A Schematic Perspective. Academy of Management Journal, 38(2), 537-554.

25. Locke, A. E. (1976). What is Job Satisfaction? Journal of Organizational Behavior and Human performance, 4(2), 309-336.

26. Luthans, F. (2006). Organizational Behavior (9th Ed). New York: McGraw-Hill. 
27. Mangkunegara, A. W. (2005). Perilaku dan Budaya Organisasi, Cetakan Pertama, Bandung: PT. Refika Aditama.

28. Mangkuprawira, S. (2009). Manajemen Sumber Daya Manusia Strategik. Jakarta: PTGhalia Indonesia.

29. Meyer, J. P., Allen, N.J., \& Smith C. A. (1993). Commitment to Organizations and Occupations: Extentions and Test of a Three Component Conceptualization. Journal of Applied Psychology, 78(7), 538-551.

30. Mitchell, S. A. (1998). Empowering People Pemberdayaan Sumberdaya Manusia. Translated Agus M. Harjono. Yogyakarta: Kanisius.

31. Morris, D. R., \& Robbert, E. N. (1994). Attribution Influences on the Job Performance-Job Satisfaction Relationship. Journal of Organization Behavior, 27 (2), 424-431.

32. Mowday, R. T., Steers, R. M., \& Porter, L. W. (2004). The Messurement of Organization (3nd Ed). Engel Wood. USA

33. Muchari. (2001). The effect of leadership style on organizational citizenship behavior and commitment (The case of railway corporation, Yogyakarta Indonesia) (Disertasi). Universitas Gajah Mada, Yogyakarta.

34. Munandar, A.S., Sjabadhyni, B., \& Wutun, R. P. (2004). Peran Budaya Organisasi dalam Peningkatan Unjuk Kerja Perusahaan. Depok: Bagian Psikologi Industri dan Organisasi Fakultas Psikologi Universitas Indonesia.

35. Muriman, C. S. (2008). Pengaruh Budaya Organisasi dan Stres Terhadap Komitmen Organisasi dan Kepuasan Kerja (studi di Kepolisian Negara RI Sektor, Kepolisian Negara RI Daerah Jawa Timur) (Disertasi). Program Pascasarjana Universitas Brawijaya, Malang.

36. Nawawi, H. (2007). Manajemen Sumber Daya Manusia Untuk Bisnis yang Kompetitif. Yogyakarta: Gajah Mada University.

37. Neale \& Noertheraft. (1990). Organizational Behavior Developing Manajerial Skill. New York: Harper and Row Publishing.

38. Nimran, U. (2005). Perilaku Organisasi. Surabaya: CV.Citra Media.

39. Nitisemito, A. S. (1996). Manajemen Personalia (Manajemen Sumber Daya Manusia), Jakarta: Ghalia Indonesia.

40. Noer, C., \& Dwiarko, N. (2014). Pengaruh Berbagi Pengetahuan Terhadap Kinerja Karyawan Melalui Kerja Tim. Jurnal IImu Manajemen, 2(3), 132-147

41. Nugroho, R. (2009). Pengaruh Karakteristik pekerjaan dan Lingkungan Kerja Terhadap Kepuasan Kerja, OCB dan Komitmen Organisasi Serta Dampaknya Pada Kinerja Pegawai Balai Yasa PT. Kereta Api Indonesia (Persero) (Disertasi). Universitas 17 Agustus 1945, Surabaya.

42. O'Driscol, M. P., \& Randal, D. M. (1999). Perceived Organizational Support, Satisfaction With Reward, and Employee Job Involvement and organizational Commitment. International Journal of Applied psychology, 48(2), 197-209.

43. Orgoer, D. W., \& Linge, A. (1995). Personality Satisfaction, and Organizational Citizenship Behavior. The Journal of Social Psychology, 135(3), 339-350.

44. Porter, L. W., \& Lawyer, E. E. (1974). Managerial Attitude and Performance. Homewood, IL: Irwin-Dorsey.

45. Rashid, M. A. A., Sambasivan, M., \& Johari, J. (2003). The Influence of Corporate Culture and Organizatioanl Commitment on Performance. Journal of Management Development. 22(8), 107-123.

46. Rini. (2004). Pengaruh Budaya Organisasi Terhadap Komitmen, Kepuasan Kerja dan prestasi Kerja (Disertasi). Universitas Brawijaya, Malang.

47. Rivai, V. (2005). Performance Appraisal. Jakarta: PT.Raja Grafindo Persada.

48. Robbins, P. S. (2006). Organizational Behavior (9th Ed). New York: Prentice Hall International.

49. Robbins, P. S., \& Judge, T. A. (2008). Organizational Behavior (9th Ed). New Jersey: Pearson Printice Hall.

50. Ruky, A. (2015). Sumber Daya Manusia Berkualitas. Jakarta: Gramedia Pustaka Utama. 
51. Sandy, C. (2012). Pengaruh Leader Member Exchange (Lmx) Terhadap Kinerja Karyawan Pada Koperasi Sejahtera Bersama Kantor Cabang Kertajaya Surabaya dengan Job Commitment Sebagai Variabel Intervening ( Disertasi ). Fakultas pascasarjana Universitas Airlangga, Surabaya.

52. Schermerhorn, J. R. Jr. (2010). Management (9th Ed). New York: John Willey and sons.

53. Sekaran, U. (2006). Research Methods for Bussiness: A skill Building Approach (2nd Ed). New York: Jhon Wiley \& Sons, Inc.

54. Slocum, J. W., \& Wallace, Jr. M. (1971). Prediction of Job Success and Employ Satisfaction. Journal of Training and Development, 34 (8) 611-129

55. Soon, D. M. (2001). The Effect Of Leadership Style and Employe's Commitment Toward Employee's Performance (Disertation Unpublished). Louisiana State University and Agricultural and Mechanical College, USA

56. Spencer \& Spencer. (2003). Competence At Work. New York: John Wiley \& Sons Inc.

57. Simamora, H, (2006). Manajemen Sumber Daya Manusia. Yogyakarta: STIE YKPN.

58. Stanton, R. (2009). Teori Fiksi Robert Stanton. Translated Sugi Hastuti dan Rssi Abi AL Irsyad). Yogyakarta: Pustaka Pelajar

59. Steers, M. R., \& Porter, M. (2004). Introduction to Organizational Behavior (4th Ed). New Jersey: Harper Collins Publisher.

60. Sopiah. (2008). Perilaku Organisasi. Penerbit Andhi Opset. Yogtakarta

61. Suprayetno, A. (2006). Pengaruh Motivasi Kerja, Kepemimpinan, dan Budaya Organisasi Terhadap Kepuasan Kerja Karyawan serta Dampaknya pada Kinerja Perusahaan (studi kasus pada PT. Pei Hai International Wiratama Indonesia) (Tesis). Universitas 17 Agustus 1945, Surabaya.

62. Suprayetno, A. (2011). Pengaruh Variabel Anteseden Kepuasan Kerja Karyawan dan Organizational Citizenship Behavior terhadap Kinerja Karyawan Industri Sepatu di Jawa Timur) (Disertasi). Universitas 17 Agustus 1945, Surabaya.

63. Suprihanto, J. (2001). Penilaian Kinerja dan Pengembangan Karyawan. Yogyakarta: Bagian Penerbitan Fakultas Ekonomi Universitas Gajah Mada.

64. Supriyanto. (2005). Pengaruh Lingkungan Kerja, Beban Kerja Dan Kompensasi Terhadap Kepuasan Kerja, Komitmen Organisasi Dan Kinerja Petugas Air Traffic Control Pada PT Angkasa Pura I (Disertasi). Universitas 17 Agustus 1945, Surabaya.

65. Susanto, B. (2002). Manajemen Tenaga Kerja, Ancaman dalam Pendayagunaan dan Pengembangan Tenaga Kerja. Jakarta: Sina Baru.

66. Swasto, B. (2003). Pengembangan SDM (Pengaruhnya terhadap kinerja dan imbalan). Malang: Bayu Media.

67. Szilagyi, A. D., \& Wallace, Jr. M. (2002). Organization Behaviour and performance. Dallas: Foresman Co.

68. Testa, M. R. (1999). Organizational Commitment, Job Satisfaction and Effort in The Service Environment. Journal of psychology, 135(2), 226-237.

69. Thoha, M. (2001). Perilaku Organisasi - konsep dasar dan aplikasinya. Jakarta: Rajawali.

70. Timpe, A. D. (2003). Performance (diterjemahkan oleh Sofyan Cikmat). Jakarta: Elex Media Komputindo.

71. Tobing, S. J. (2006). Pengaruh Budaya Organisasi, Kepuasan Kerja, dan Motivasi Terhadap Komitmen Organisasi dan Kinerja (studi kasus pada PT. Astra Agro Lestari Tbk Jakarta) (Disertasi). Universitas Brawijaya, Malang.

72. Umar, H. (2005). Sumber Daya Manusia dalam Organisasi. Jakarta: PT.Gramedia Pustaka Utama.

73. Wahyuningrum. (2008). Hubungan Kemampuan, Kepuasan dan Disiplin Kerja Dengan Kinerja Pegawai Di Kecamatan Tanggungharjo Kabupaten Grobogan (Disertasi. Program Pascasarjana Universitas Diponegoro, Semarang.

74. Werther, Jr., William, B., \& Keith, D. (1998). Human Resources and personal Management (4th Ed). Singapore: McGraw-Hill, Inc.

75. Wexley, K. N., \& Yulk, G. (1997). Perilaku Organisasi dan Psikologi dan Psikologi Personalia. Translated Muh Shobaruddin. Jakarta: Rineka Cipta. 
76. Yousef, D. A. (2000). Organizational Commitment and Job Satisfaction as Predictore of Attitudes toward Organizational Change in a Non-Western Setting. Journal of personal Review, 29(5), 567-592.

77. Yousef, D. A. (2001). Organizational Commitment: A Mediator of the Relationships of Leadership Behavior with Job Satisfaction and Performance in a Non-Westerns Country. Journal of managerial Psychology, 15(1), 6-28.

78. Yulianto. (2011). Hubungan Kesejahteraan, Disiplin Kerja, Lingkungan Kerja Dan Kepuasan Kerja Dengan Kinerja Guru Sekolah Menengah Kejuruan Negeri 2 Kabupaten Sragen. (Disertasi). Program Pascasarjana Universitas Sebelas Maret, Surakarta. 